\title{
Does the contact time of alginate with plaster cast influence its properties?
}

\section{Mariana Marquezan \\ Estela Maris Jurach \\ Vanessa Domingues Guimarães \\ Raquel Gomes Almeida Valentim \\ Lincoln Issamu Nojima \\ Matilde da Cunha Gonçalves \\ Nojima}

Department of Pedodontics and Orthodontics, School of Dentistry, Universidade Federal do Rio de Janeiro, Rio de Janeiro, RJ, Brazil.
Declaration of Interests: The authors certify that they have no commercial or associative interest that represents a conflict of interest in connection with the manuscript.

Corresponding author:

Matilde da Cunha Gonçalves Nojima

E-mail: matildenojima@uol.com.br

Received for publication on Oct 23, 2011 Accepted for publication on Jan 19, 2012
Abstract: The aim of this study was to verify the influence of the time of contact between alginate and gypsum after the modeling procedure on the properties of the plaster cast, such as surface detail, dimensional stability and microhardness. Thirty cylindrical specimens of orthodontic gypsum Type III were made by means of impressions of a stainless steel master model which had five reference lines in the upper surface. The samples were divided into two groups: Group 1 (G1) - with time of contact of 1 hour; and Group 2 (G2) - 12 hours of contact. All the specimens were stored up to 48 hours until they underwent laboratory testing. Surface detail and dimensional stability were tested by one calibrated examiner using a visual analysis and a profilometer (Profile Projector Nikon model 6C, Nikon Corporation, Tokyo, Japan), respectively, to evaluate the quality of reproduction of the lines and the distances between them. The microhardness was determined for each sample by making six indentations with a Vickers diamond pyramid indenter (Buehler, Lake Bluff, USA) under a load of $100 \mathrm{gF}$ for $15 \mathrm{~s}$. The results showed significant difference $(\mathrm{P} \leq 0.05)$ between groups in two of the three properties examined: surface detail and microhardness, which decreased as the time of contact rose. The 12-hour time of contact between alginate and the plaster cast is not recommended because it influences the quality of the plaster cast.

Descriptors: Dental Impression Materials; Calcium Sulfate; Surface Properties; Hardness.

\section{Introduction}

Plaster casts have long been used in Dentistry for the purposes of diagnosis and treatment planning, because they allow a tridimensional evaluation of dental occlusion. ${ }^{1}$ They constitute records of the dental arches and must present high quality and precision. ${ }^{2}$

The plaster cast quality is related to the materials chosen and the way they are manipulated. Dentists should be informed about the advantages and disadvantages of each material to use them adequately in clinical practice. ${ }^{3}$ Alginate and gypsum are materials extensively used to make impressions and casts, respectively. ${ }^{4,5}$

The alginate presents problems with dimensional stability over time, and water loss causes roughness on the plaster surface, therefore it is not recommended for the construction of indirect restorations. ${ }^{4}$ However, it has been the material of choice for making orthodontic study models, 
because it is easy to use, is well accepted by the patient, has low cost, ${ }^{4,6,7}$ and presents adequate dimensional stability, provided that the manufacturer's instructions as regards pouring time are followed.

Professionals should take care to follow manufacturer's recommendations. The technical criteria for manipulation, such as the proportion of powder and water, mixing time, water temperature, jellification time of alginate, method for disinfecting impressions, storage time of alginate, and gypsum setting time (related to the time of contact between alginate and gypsum) must be observed to guarantee the quality of casts. Compatibility between materials must also be observed. Some alginates are not compatible with some types of gypsum, resulting in inadequate models. ${ }^{6,8}$

The aim of this study was to evaluate the influence of the time of contact between the alginate impression and gypsum poured into it on the quality of the cast, by analyzing the surface detail, dimensional stability and microhardness.

\section{Methodology}

A cylindrical stainless steel master model was used to make 30 standardized samples of orthodontic gypsum Type III (Max Polo Gesso Ltda., Rio de Janeiro, Brazil). The upper surface of the stainless steel cylinder had three reference lines of different widths: $\mathrm{A}=75 \mu \mathrm{m} ; \mathrm{A}^{\prime}=50 \mu \mathrm{m}$, and $\mathrm{A}^{\prime \prime}=25 \mu \mathrm{m}$; intercepted by two perpendicular lines, located near the outer contour of the cylinder, called B and B', both $75 \mu \mathrm{m}$ wide (Figure 1).

To prepare the specimens, the manufacturer's recommendations were followed. First, alginate (Jeltrate, Dentsply Ind. Com., Petrópolis, Brazil) was manually mixed for 45 seconds, and then inserted into a rubber ring, which was coupled to the metal cylinder and acted as a tray. After this, the ring was covered with a glass plate (weight $400 \mathrm{~g}$ ) in order to shape the impression. The set remained immobile for 3 minutes, corresponding to the jellification time of alginate. Finally, the ring and cylinder were separated and an alginate impression was obtained.

Immediately after making the impressions, the orthodontic plaster was manipulated under vacuum for 30 seconds and then it was gradually poured

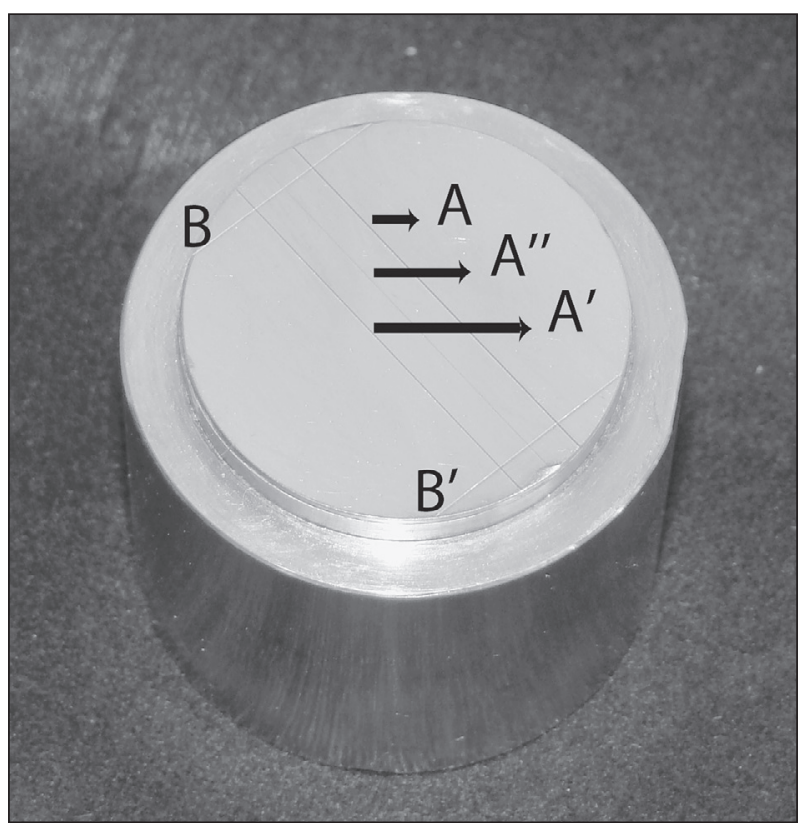

Figure 1 - Upper surface of the stainless steel cylinder, in which the lines $A\left(75 \mu \mathrm{m}\right.$ wide), $A^{\prime}(50 \mu \mathrm{m}), A^{\prime \prime}(25 \mu \mathrm{m}), B$ and $B^{\prime}$ (both measuring $75 \mu \mathrm{m}$ in width) may be seen.

onto the alginate surface under vibration at low speed. When the impression was completely filled with gypsum, the glass plate was placed on it and kept under slight pressure (400 gF - exerted by weight of the glass plate), in order to flatten the surface and shape the specimen.

The samples were randomly divided into two groups:

- Group 1 (G1), in which the cast remained in contact with the alginate for 1 hour (Control Group); and

- Group 2 (G2), in which contact between the materials was maintained for $12 \mathrm{~h}$.

All the specimens were stored (up to 48 hours) in a plastic receptacle with small holes in it, until they underwent laboratory testing. Surface detail, dimensional stability and Vickers microhardness were tested by one calibrated examiner.

\section{Surface detail}

An index was created to evaluate the quality of reproduction of the lines A, A' and A" (Table 1). Evaluations were performed at $4 \times$ magnification (Aus Jena, Germany) and under artificial light (100 watts). 
Table 1 - Surface detail index to evaluate the impression surface.

\begin{tabular}{c|l}
\hline Score & \multicolumn{1}{c}{ Impression surface } \\
\hline 0 & None of the 3 lines were visible \\
\hline 1 & Only line $A(75 \mu \mathrm{m})$ was clear \\
\hline 2 & $\begin{array}{l}\text { Line } A(75 \mu \mathrm{m}) \text { was clear and line } A^{\prime}(50 \mu \mathrm{m}) \text { presented } \\
\text { up to } 2 \text { interruptions }\end{array}$ \\
\hline 3 & Lines $A(75 \mu \mathrm{m})$ and $A^{\prime}(50 \mu \mathrm{m})$ were clear \\
\hline 4 & Lines $A(75 \mu \mathrm{m}), A^{\prime}(50 \mu \mathrm{m})$ and $A^{\prime \prime}(25 \mu \mathrm{m})$ were clear \\
\hline
\end{tabular}

\section{Dimensional stability}

Dimensional stability was evaluated by taking one measurement for each specimen from line B to B'. The Profile Projector Nikon profilometer, model 6C (Nikon Corporation, Tokyo, Japan) was used for taking the measurements.

\section{Vickers microhardness}

Vickers microhardness was determined for each sample by making six indentations in different regions along lines $\mathrm{A}, \mathrm{A}$ ' and A" using a Vickers diamond pyramid indenter (Buehler, Lake Bluff, USA) under a load of $100 \mathrm{gf}$ for $15 \mathrm{~s}$.

\section{Statistical analysis}

Statistical analysis was performed using the Statistical Package for the Social Sciences software (version 17, SPSS Inc., Chicago, USA). The difference between groups for the scores of the variable surface detail was assessed by the Chi-square test. The values obtained for the scale variables, dimensional stability and microhardness were tabulated and submitted to normality and homogeneity tests (Shapiro-Wilk and Levene) at a 0.05 level of significance. Once normality and homogeneity were verified for these variables, Student's- $t$ test was applied.

\section{Results}

The results of the Surface detail index are shown in Table 2. Statistically significant difference was found between Group G1 and G2 (P = 0.001). The results of the variables dimensional stability and Vickers microhardness are shown in Tables 3 and 4, respectively.
Table 2 - Frequency distribution of the surface detail index.

\begin{tabular}{c|c|c|c|c|c}
\hline & \multicolumn{5}{|c}{ Surface detail index } \\
\cline { 2 - 6 } & Score 0 & Score 1 & Score 2 & Score 3 & Score 4 \\
\hline $\begin{array}{c}\text { G1 count } \\
\text { (\% within } \\
\text { group) }\end{array}$ & 0 & 0 & 1 & 11 & 3 \\
\hline $\begin{array}{c}\text { G2 count } \\
(\% \text { within } \\
\text { group) }\end{array}$ & $\begin{array}{c}0 \%) \\
(0 \%)\end{array}$ & $\begin{array}{c}0 \\
(0 \%)\end{array}$ & $\begin{array}{c}9 \\
(60 \%)\end{array}$ & $\begin{array}{c}(33.33 \%) \\
(73.33 \%)\end{array}$ & $\begin{array}{c}(20 \%) \\
(6.66 \%)\end{array}$ \\
\hline
\end{tabular}

Table 3 - Descriptive statistics for dimensional stability (mm).

\begin{tabular}{c|c|c|c}
\hline & Mean & Standard deviation & $P$ value \\
\hline G1 & 25.07 & 0.04 & 0.3 \\
\hline G2 & 25.08 & 0.05 & \\
\hline
\end{tabular}

Table 4 - Descriptive statistics for Vickers microhardness $\left(\mathrm{kgf} / \mathrm{mm}^{2}\right)$.

\begin{tabular}{c|c|c|c}
\hline & Mean & Standard deviation & $P$ value \\
\hline G1 & 169.72 & 52.41 & 0.039 \\
\hline G2 & 133.53 & 37.19 & \\
\hline
\end{tabular}

\section{Discussion}

The results of this study showed that when the time of contact between alginate and plaster was increased (G2), it produced damage to the cast surface quality, reducing the surface richness of detail and microhardness, even though it had no influence on its dimensions.

The International Standards Organization (ISO) has a standard technique for performing alginate impressions: ISO 1563:1990, ${ }^{9}$ which states that the dental casts obtained from alginate molds must reproduce lines of $50 \mu \mathrm{m}$ in width. The scores 3 and 4 of the surface detail index created in this research are consistent with the standard technique. The results of this study showed that $93.33 \%$ of the specimens from the control group (G1) were in compliance with the standard technique, however, most of the specimens in Group 2 (12 hours of contact between plaster and alginate) had score 2 , and did not comply with the ISO standard.

In addition to the loss of detail, the microhard- 
ness of the cast was also reduced by increasing the time of contact between plaster and alginate. The literature reports that alginate does not have dimensional stability, and it is necessary to pour the plaster immediately after molding has been completed, ${ }^{10,11}$ or within up to 60 minutes if the impression is kept in $100 \%$ humidity, ${ }^{12}$ because alginate undergoes syneresis resulting in contraction. ${ }^{11}$ It is a good practice to separate the model and the cast before the hydrocolloid dehydrates because the dried alginate can cause abrasion of the cast during its removal. ${ }^{13}$ Although no visible abrasion was verified in the casts in this survey, loss of richness in detail and reduced microhardness observed were probably due to alginate dehydration.

The literature confirms that alginate impression materials have less stability and accuracy when the storage time of alginate increase, ${ }^{13-15}$ but the time of contact between alginate and gypsum has not been tested before. This study showed that the dimensional stability of the casts was not affected by increasing the time of contact between alginate and plaster. Although the dry alginate undergoes dimensional changes if it is not cast in plaster, it was found that the plaster model did not undergo dimensional changes when the contact time between plaster and alginate was increased. This is probably due to the fact that orthodontic plaster (type III) has smooth and acceptable setting expansion ${ }^{16,17}$ and is not influenced by alginate contraction, considering this

\section{References}

1. Habib F, Fleischmann LA, Gama SKC, Araújo TM. Obtenção de modelos ortodônticos. R Dent Press Ortodon Ortop Facial. 2007 Mai-Jun;12(3):146-56.

2. Rudd KD, Morrow RM, Bange AA. Accurate casts. J Prosthet Dent. 1969 May;21(5):545-54.

3. Pereira JR, Murata KY, Valle AL, Ghizoni JS, Shiratori FK. Linear dimensional changes in plaster die models using different elastomeric materials. Braz Oral Res. 2010 JulSep;24(3):336-41.

4. Faria ACL, Rodrigues RCS, Macedo AP, Mattos MGC, Ribeiro RF. Accuracy of stone casts obtained by different impression materials. Braz Oral Res. 2008 Oct-Dec;22(4):293-8.

5. Hansson O, Eklund J. A historical review of hydrocolloids and an investigation of the dimensional accuracy of the new property.

This study has elucidated some of the consequences of increasing the time of contact between alginate and gypsum, however, this factor must be tested under other conditions to simulate the clinical routine, for example, performing disinfection of the casts, ${ }^{18,19}$ as well as using $100 \%$ humidity while the plaster undergoes setting to avoid alginate syneresis. Further research is also suggested using other times of contact between alginate and plaster, longer than 1 hour, but shorter than 12 hours.

\section{Conclusion}

The increased time of contact between alginate and plaster produces damage to the cast surface quality, reducing the surface richness of detail and microhardness, even though it had no influence on its dimensions.

\section{Acknowledgments}

The authors would like to express their thanks to Prof. Orlando Chevitarese (in memoriam) for his teachings and legacy, to Dr. Marcela Marquezan for statistical support, to the Brazilian Government through CAPES (Coordenação de Aperfeiçoamento de Pessoal de Nível Superior) for the financial support provided, to the Institutes IME (Instituto Militar de Engenharia) and COPPE (Instituto Alberto Luiz Coimbra de Pós-Graduação e Pesquisa em Engenharia) for the cooperation and technical support.

alginates for crown and bridge impressions when using stock trays. Swed Dent J. 1984;8(2):81-95.

6. Reisbick MH, Johnston WM, Rashid RG. Irreversible hydrocolloid and gypsum interactions. Int J Prosthodont. 1997 JanFeb;10(1):7-13.

7. Nandini VV, Venkatesh KV, Nair KC. Alginate impressions: a practical perspective. J Conserv Dent. 2008 Jan;11(1):37-41.

8. Paffenbarger GC. Guide to dental materials and devices: a historical review. J Am Dent Assoc. 1972 Jun;84(6):1333-5.

9. International Standards Organization. Specification for alginate impression material - 1563. 2nd ed. Geneve: ISO; 1990. $7 \mathrm{p}$.

10. Araújo JEJ, Moraes JV. Alginato armazenamento em cuba umidificadora e tratamento de superfície. Rev Bras Odontol. 1993 Mai-Jun;50(3):38-41. 
11. Oliveira AR, Jóias RM. Dimensional evaluation of molds of irreversible hydrocolloid after disinfection. Rev Odonto. 2009 Jan-Jun;17(33):54-62.

12. Schleier PE, Gardner FM, Nelson SK, Pashley DH. The effect of storage time on the accuracy and dimensional stability of reversible hydrocolloid impression material. J Prosthet Dent. 2001 Sep;86(3):244-50.

13. Chen SY, Liang WM, Chen FN. Factors affecting the accuracy of elastomeric impression materials. J Dent. 2004 Nov;32(8):603-9.

14. Walker MP, Burckhard J, Mitts DA, Williams BK. Dimensional change over time of extended-storage alginate impression materials. Angle Orthod. 2010 Nov;80(6):1110-5.

15. Nassar U, Aziz T, Flores-Mir C. Dimensional stability of irreversible hydrocolloid impression materials as a function of pouring time: a systematic Review. J Prosthet Dent. 2011 Aug;106(2):126-33.
16. American Dental Association. Resert American National Standards Institute/ American Dental Association specification n 25 for dental gypsum products. J Am Dent Assoc. 1981 Mar;102(3):351.

17. Ferreira RA, Nagem Filho H, Pinto JHN. Determinação da magnitude de expansão de alguns tipos de gesso. Salusvita. 2000;19(2):29-39.

18. Lemos IS, Porto RO, Alves BP, Jassé FF, Galvão MR, Andrade MF, et al. Avaliação da alteração dimensional de modelos obtidos a partir de moldagens com alginato tradicional e outro com desinfetante. Rev Odontol UNESP (Online). 2010 JanFev;39(1):41-7 [citado 26 fev. 2012]. Disponível em: http:// rou.hostcentral.com.br/.

19. Rentzia A, Coleman DC, O’Donnell MJ, Dowling AH, O'Sullivan M. Disinfection procedures: their efficacy and effect on dimensional accuracy and surface quality of an irreversible hydrocolloid impression material. J Dent. 2011 Feb;39(2):133-40. 